\title{
The effects of four repellents on bank vole consumption and germination of beech nuts and acorns
}

\author{
Adrian Villalobos $^{1}$ D $\cdot$ Gert Olsson $^{2} \cdot$ Maria Birkedal $^{3} \cdot$ Magnus Löf $^{1}$
}

Received: 31 December 2017 / Accepted: 24 June 2018 / Published online: 28 June 2018

(c) The Author(s) 2018

\begin{abstract}
Consumption and removal of buried seeds by granivorous rodents is one of the major problems when direct seeding is applied for restoration of oak (Quercus robur) and European beech (Fagus sylvatica) forests. In this laboratory study, the use of four seed treatments to potentially reduce bank vole (Myodes glareolus) consumption of beech nuts and acorns and a control was evaluated using a no-choice feeding set-up. The five seed treatments were: Chili (Capsicum chinense)/coconut fat, citronella (Cymbopogon winterianus)/rapeseed oils, mink (Mustela vision) excrement, sand coating as a physical barrier and a control. Seed germination tests were carried out with all the treatments. A total of 40 bank voles were individually given access to beech nuts or acorns at a rate of one treatment per day during two sessions. Mink excrement and chili/coconut fat treatments greatly reduced the consumption of beech nuts, and also reduced touching of beech nuts and acorns. In contrast, the sand coating treatment increased the consumption of both types of seeds. Germination of both beech nuts and acorns was reduced by the chilli/coconut fat and citronella/rapeseed oils treatments. Our results suggest that mink excrement has a potential as an effective repellent against bank voles when direct seeding is applied. However, further studies to determine the best method of application, as well as the efficiency under field conditions, are needed before definitive recommendations can be given to restoration managers.
\end{abstract}

Keywords Broadleaved forests $\cdot$ Pest-management $\cdot$ Regeneration $\cdot$ Sowing $\cdot$ Seed predation

Electronic supplementary material The online version of this article (https://doi.org/10.1007/s1105 6-018-9660-6) contains supplementary material, which is available to authorized users.

Adrian Villalobos

adrian.villalobos@slu.se

1 Southern Swedish Forest Research Centre, Swedish University of Agricultural Sciences, Box 49, 23053 Alnarp, Sweden

2 Department of Wildlife, Fish and Environmental Studies, Swedish University of Agricultural Sciences, 90183 Umeå, Sweden

3 Södra Skog, Friluftsvägen 2, 24330 Höör, Sweden 


\section{Introduction}

In central Europe and southern Scandinavia the high productivity of conifers such as Norway Spruce (Picea abies L.) and Scots pine (Pinus sylvestris L.) has been favored by the forest industry, largely replacing the original mixed broadleaved forest (Madsen and Löf 2005; Löf et al. 2012; Lindbladh et al. 2014). To adapt forest management to climate change, lower economic risks and increase biodiversity, the restoration of temperate broadleaved forests including Pedunculate oak (Quercus robur L.) and European beech (Fagus sylvatica L.) has been advocated (Koca et al. 2006; Bolte et al. 2009). However, this is usually an expensive option. Similar to other restoration situations, expensive plant material and plantations, and the need to protect young trees from browsing animals leads to very high costs (Chazdon 2008; Ceccon et al. 2016). Thus, the development of low-cost alternatives for forest restoration is needed.

Direct seeding of beech and oak has the potential to become such a method (Madsen and Löf 2005). However, the high consumption and removal rates of their seeds by granivorous rodents (e.g. in Scandinavia the yellow-necked mouse Apodemus flavicollis Melchior, the wood mouse Apodemus sylvaticus L., and the bank vole Myodes glareolus Schreber) limits the implementation of direct seeding as a reliable method (Madsen and Löf 2005; Birkedal et al. 2009; Smit et al. 2009; González-Rodríguez and Villar 2012).

Previously, several techniques have been implemented to reduce negative effects of rodent seed predation. This include the use of rodenticides (Myllymäki 1975) which for environmental and regulatory reasons often is no longer allowed, mechanical site preparation of restoration areas (Löf and Birkedal 2009), and diesel submersion of seeds as a chemical repellent (Bäumler et al. 1990; Leverkus et al. 2017). Other methods for example are spreading of sunflower seeds and oats mixed with seeds of Douglas fir (Pseudotsuga menziessi (Mirb.) Franco) to satiate seed predators and decrease consumption of the conifer seeds (Sullivan 1979). Planting acorns at different depths has been tried to reduce the capacity of rodents to find seeds (Nilsson et al. 1996). Moreover, physical protectors for acorns such as seeding tubes (Madsen and Löf 2005), wire mesh cylinders (Reque and Martin 2015) and polyethylene seed shelters (Castro et al. 2015) have also been developed and tried. However, these studies have either not led to satisfactory protection of seeds or led to reduced germination capacity, or have increased costs in term of environmental impact, material and time required.

An alternative method to keep rodents away from newly sowed areas is natural repellents developed from the scent of their predators. As a main prey for several mammal predators and raptors, rodents have evolved many antipredator behaviors (Hansson 1971; Ylönen et al. 2003). Hence, forest-living voles and mice select habitats with sufficient ground vegetation, fallen trees and stones suitable for provision of food and shelter (Hansson 1971; Olsson et al. 2005; Birkedal et al. 2010). As rodents are mainly nocturnal, their complex olfactory system plays a key role in foraging, detecting predation risk and identifying toxic or repellent substances (Vander Wall 1998; Hansen et al. 2015). Substances in predator odors derived from feces, urine, scent glands, skin or fur are known to repel rodents (Stoddart 1976; Sullivan et al. 1988; Jędrzejewski et al. 1993; Borowski 1998; Apfelbach et al. 2005). Moreover, several plant-based repellents have also been shown to repel rodents (Hansen et al. 2015). For example, capsaicin-one of the principal components of chili-creates a burning sensation in mammals' mouths (Szolcsanyi 1990). Capsaicin has previously been tested and found effective as a repellent against rodents (e.g. Nolte and Barnett 2000; Jensen et al. 2003). Citronella oil is another plant-based substance that 
has been used as an insect repellent (Biswas and Biswas 2006). Only a few studies have, however, addressed the use of such chemical repellents in order to deter rodents from seed consumption of European broadleaved trees (Bäumler et al. 1990; Willoughby et al. 2011; Leverkus et al. 2013; Sunyer et al. 2013; Leverkus et al. 2017).

In this study, we investigated the effects of four different seed protective treatments against bank vole consumption of beech nuts and acorns, and these treatments' effect on seed germination. The four protective treatments were: Seeds treated with chili (Capsicum chinense Jacq) and coconut fat, citronella (Cymbopogon winterianus Jowitt) with rapeseed oils, mink (Neovison vison Schreber) excrement and sand coating of the seeds. Sand coating as a mechanical barrier against feeding on seedling shoots by roe deer (Capreolus capreolus L.) and on seedling stems by pine weevils (Hylobious abietis L.) has previously been tested and used successfully (Bergquist and Örlander 1996; Nordlander et al. 2009). However, such treatment has not previously been evaluated for seed protection against rodents. Thus, the specific objectives of this study were: (1) to assess the potential repellent effects of these four seed treatments on bank voles' consumption of beech nuts and acorns, (2) to compare differences of bank vole seed consumption between beech nuts and acorns, and (3) to determine their effect on germination of beech nuts and acorns.

\section{Materials and methods}

\section{Vole and seed materials}

A total of 40 laboratory-bred bank voles were used in feeding trials at the Astrid Fagraeus Laboratory, Solna, Sweden in August 2007. Voles were bred at the same laboratory and were at least 2 months old and none of them had previously experienced other kinds of experiments. Prior to experiments, all voles weighed between 14.4 and $26.7 \mathrm{~g}$ and they had been kept as same-sex pairs in cages $\left(60 \times 30 \times 40 \mathrm{~cm}^{3}\right)$ at a room temperature of $19{ }^{\circ} \mathrm{C}$ and $88 \%$ humidity. Voles were kept with an artificial light regime with $12 \mathrm{~h}$ daylight, and $12 \mathrm{~h}$ darkness including "lunar light" created by a diode with whitish/bluish light. Pelleted mouse food (RM1, Special Diet Services, UK) was supplied between trials and water ad libitum between and during the feeding experiments.

Different seed lots were used for the feeding experiments and germination tests. For the feeding experiments, F. sylvatica (Haderslev F.692, Denmark, 2006) and Q. robur (PL-RD 0346, Poland, 2006) were used; these seeds were previously stored at the Statsskovenes Planteavlsstation nursery, in Humlebæk, Denmark. According to a cut-test, the viability of these beech nuts and acorns at the start of the experiment was $80 \%$. For the germination tests, F. sylvatica (Skäralid 083, Sweden 2006) and Q. robur (Flakulla 138, Sweden, 2007) were used and had been stored at the Ramlösa plantskola nursery in Helsingborg, Sweden. Beech nuts were pre-treated to break dormancy, and thereafter from the time of delivery and until start of experiments, all seeds were stored at $4{ }^{\circ} \mathrm{C}$. Otherwise, all seeds had been stored and handled according to international guidelines (Rao et al. 2006).

\section{Seed treatments}

The amounts and proportions of different ingredients used to prepare the treatments with beech nuts and acorns for the no-choice experiment and the germination tests are given in Table 1. The methods of preparing the five seed treatments were as follows: 
Table 1 Contents of repellent substances used for the five seed treatments. Mink excrements were obtained from a mink farm in southern Sweden. Minks were feed with a diet based on fish protein

\begin{tabular}{lll}
\hline Treatment & Content & Amount (proportion) \\
\hline Control & Water & $3000 \mathrm{ml}(100 \%)$ \\
Chilli/coconut fat & Habanero chili (dry weight) & $19 \mathrm{~g}(1.3 \%)$ \\
& Coconut fat & $1500 \mathrm{~g}(98.7 \%)$ \\
Citronella/rapeseed oil & Citronella oil, Java & $45 \mathrm{ml}(1.5 \%)$ \\
& Rapeseed oil & $3000 \mathrm{ml}(97.5 \%)$ \\
Mink excrement & Mink excrement (wet weight) & $400 \mathrm{~g}(11.8 \%)$ \\
& Water & $3000 \mathrm{ml}(88.2 \%)$ \\
Sand coating & Sand & $2500 \mathrm{ml}(55.8 \%)$ \\
& Water & $1600 \mathrm{ml}(35.7 \%)$ \\
& Potato starch & $200 \mathrm{ml}(4.5 \%)$ \\
& Sugar & $180 \mathrm{ml}(4.0 \%)$ \\
\hline
\end{tabular}

Control (1) —seeds were soaked in water.

Chili/coconut fat (2)—small pieces of habanero chili peppers were mixed into melted coconut fat (carrier) and seeds were dipped into the substance when it had cooled down and before it coagulated. Other pieces of habanero chilies were dried at $60{ }^{\circ} \mathrm{C}$ for $24 \mathrm{~h}$ to determine their dry weights.

Citronella/rapeseed oil (3) — seeds were soaked in a mixture of citronella oil (Java, $3-15 \%$ citronella, $85-97 \%$ geraniol) and rapeseed oil (carrier).

Mink excrement (4)—seeds were soaked in water (carrier) to which mink excrements (obtained from a mink farm in southern Sweden) was added.

Sand coating (5) - potato starch was boiled in water and stirred until it formed a thick paste. After removing the paste from the heat, sugar and sand were added, and the seeds coated by dipping them into the cooled mixture.

Using water as an admixture substance with chili and citronella was not possible. Therefore, the admixtures were performed with fats as carriers. Following preparation, all seeds were air-dried and afterwards refrigerated until used in experiments within 1-11 days.

\section{Experimental design and measurements}

The no-choice feeding trials were conducted in two sessions of five consecutive days each using 20 male and 20 female bank voles. For each vole and session, days and treatments were arranged in a series of $5 \times 5$ Latin Squares in order to control for any possible influence of the previous day's treatment. Thus, each vole experienced a different sequence of treatments from all other voles during each session. However, each vole experienced the same sequence of treatments in session two as it had in session one.

The bank voles used were divided into two groups: 12 males and 8 females used for the treatments with beech nuts, and 8 males and 12 females used for the treatments with acorns. During the feeding trials individual voles were placed in the same types of cages as they previously were kept in, but cleaned and provided with treated beech nuts or acorns on the opposite side from the cage entrance. On the floor, all cages contained wood chips enriched with a paper sheet. The differences in seed size (i.e. volume and surface area) between acorn and beech nuts were considered. Therefore, twice as many treated beech nuts $(n=10)$ compared to treated acorns $(n=5)$ were used for each individual vole and 
cage in the behavioral experiments. The allocated treatment was placed on the bottom of the cage. No other food was available during the seven daytime hours that the trials lasted. All trials were considered non-harmful to the animals and ethically approved (Dnr N104/07). Before the no-choice feeding trial two male voles died after fighting with their cage companions and one escaped from the cage. These individuals were removed from the dataset.

Treated beech nuts and acorns were weighed in grams before and after each trial. To avoid an overestimation of seed consumption we also collected and weighed repellent substance rubbed off from the seeds by the bank voles, or in cases such as in treatments 2 and 5 (Chili/coconut and Sand coating) where these coatings had a tendency to be rubbed off during the trials. Cages were recorded as 0 if any of the seeds presented had been handled by the bank voles, and if all seeds were untouched during the trial the cage was recorded as 1 . As a measure to determine water loss or uptake by the seeds, samples of treated seeds were placed in open jars in the same room as the trials and weighed before and after trials.

\section{Germination tests}

The tests of germination capacity were carried out at the Statsskovenes Planteavlsstation nursery, in Humlebæk, Denmark between May and August 2008. One sample of 200 seeds for each species and treatment combination (i.e. two seed species, five treatments including control), thus in total 2000 seeds were used. Beech nuts were kept in vermiculite at $5^{\circ} \mathrm{C}$ for 1 week, and thereafter at $5{ }^{\circ} \mathrm{C}(8 \mathrm{~h}) / 15^{\circ} \mathrm{C}(16 \mathrm{~h})$ until germination. After 14 weeks beech nuts that had not germinated were cut to determine their viability. Acorns were kept in sand at $4{ }^{\circ} \mathrm{C}$ for three weeks and thereafter at $20{ }^{\circ} \mathrm{C}(8 \mathrm{~h}) / 25^{\circ} \mathrm{C}(16 \mathrm{~h})$ until germinants (the first pair of leaves) developed. After 14 weeks the status (alive or dead) of the root was determined for germinated acorns where no germinant had yet developed.

\section{Statistical analysis}

All analyses were performed using $\mathrm{R}$ version 3.2.3 (R Core Team 2015). The effects of repellent treatments on seed consumption were analyzed using generalized linear mixed models (GLMM) implemented with the function 'glmer' in the R package 'lme4' (Bates et al. 2015). We included grams of seed consumption as the response variable, and the variables treatment (5 levels), seed species (2 levels), and sex (2 levels) as fixed effects, and day and vole (nested with Session) as random effects. We specified a lognormal error distribution, and because the mean of the response variable was $<5$, we performed the Laplace approximation in our model (Bolker et al. 2009). Interactions between fixed effects were tested by an analysis of deviance for unbalanced design (Wald $X^{2}$ Type III). To enable post hoc comparisons of different repellents across sex (females and males) and seed species (acorns and beech nuts), an interaction analysis for estimated marginal means was performed using the R package 'emmeans' (Lenth 2018). We assessed overdispersion of the model using the function 'overdisp_fun' (Bolker 2018) and checked model overparameterization using a leave-one-out cross-validation. This analysis revealed no overdispersion or overparameterization in the model. Treatment effects on bank vole seed handling (touched and untouched seeds) was analyzed with a generalized linear model (GLM) with a quasibinomial error distribution for overdispersed data (Demétrio et al. 2014). A post analysis of deviance (Likelihood ratio $X^{2}$ Type III) revealed no significance of sex as predictor variable (Online resource $3 \mathrm{c}$ ). Hence we simplified the model with only seed species and treatment 
as predictors. $F$-tests suitable for unpaired data were used as a post hoc test to compare the likelihood of voles touching acorns and beechnuts in each treatment. To evaluate the impacts of treatments on seed germination, a GLM with quasi-binomial error distribution was carried out. Here we included percentage of germinated seeds as response variable and treatment and seed species as predictors. Factor effects were significant for this analysis (Online resource 5c). The significance level for all the tests was set at $\alpha=0.05$.

\section{Results}

There was a strong effect of treatment on seed consumption $\left(X^{2}=325.14, D f=4, p \geq 0.01\right)$, and an interaction between treatment and seed species $\left(X^{2}=21.72, D f=1, p \geq 0.01\right)$. Furthermore, there was an interaction between treatment and sex $\left(X^{2}=21.76, D f=1, p \geq 0.01\right)$ (Table 2).

In comparison with the control, the mink excrement, chili/coconut fat and citronella/ rapeseed treatments significantly reduced the consumption of beech nuts by both males and females (Fig. 1, Online Resource 1). Consumption of acorns by males showed the same trends with the exception for chili/coconut fat and citronella/rapeseed treatments. Additionally, females consumed less citronella/rapeseed treated acorns when compared with all other treatments. No differences in consumption for beech nuts and acorns treated with chili/coconut fat, citronella/rapeseed and mink excrement were found. However, significant differences were found between the chili/coconut fat and citronella/rapeseed treatments for acorns consumed by females $(Z=3.02, \mathrm{SE}=0.22, p=0.02)$. The sand coating totally failed as a repellent. In both seed types and for males and females, bank voles consumed more seed mass (Fig. 1) when coated with sand (mean consumption $=4.92 \mathrm{~g}$, standard deviation $=1.74$ ) compared to untreated seeds (mean consumption $=1.68$, standard deviation $=0.83)$. Seeds treated with sand coating consumed by females $(Z=-3.85, \mathrm{SE}=0.11$

Table 2 Interactions of fixed effects with seed consumption. Main effect interactions were derived a posteriori from generalized linear mixed models with a lognormal error distribution using an analysis of deviance for unbalanced design (Wald $X^{2}$ Type III). Model random effects variance listed at the end of the table

\begin{tabular}{lccc}
\hline Fixed effects/interactions & \multicolumn{1}{l}{$\chi^{2 *}$} & $D f^{* *}$ & $p\left(>\left|\chi^{2}\right|\right)$ \\
\hline Treatment & 325.14 & 4 & $<0.01$ \\
Seed species & 1.18 & 1 & 0.28 \\
Sex & 0.50 & 1 & 0.48 \\
Treatment*seed species & 21.72 & 4 & $<0.01$ \\
Treatment*sex & 22.76 & 4 & $<0.01$ \\
Seed species*sex & 1.22 & 1 & 0.27 \\
Treatment*seed species*sex & 22.71 & 4 & $<0.01$ \\
\hline Random effects & Variance & & SD*** \\
\hline Session: vole & 0.02 & & 0.15 \\
Vole & 0.03 & & 0.16 \\
Day & 0.01 & & 0.07 \\
Residual & 0.46 & & 0.68 \\
\hline
\end{tabular}

*Chi square; **Degrees of freedom; ***Standard deviation 


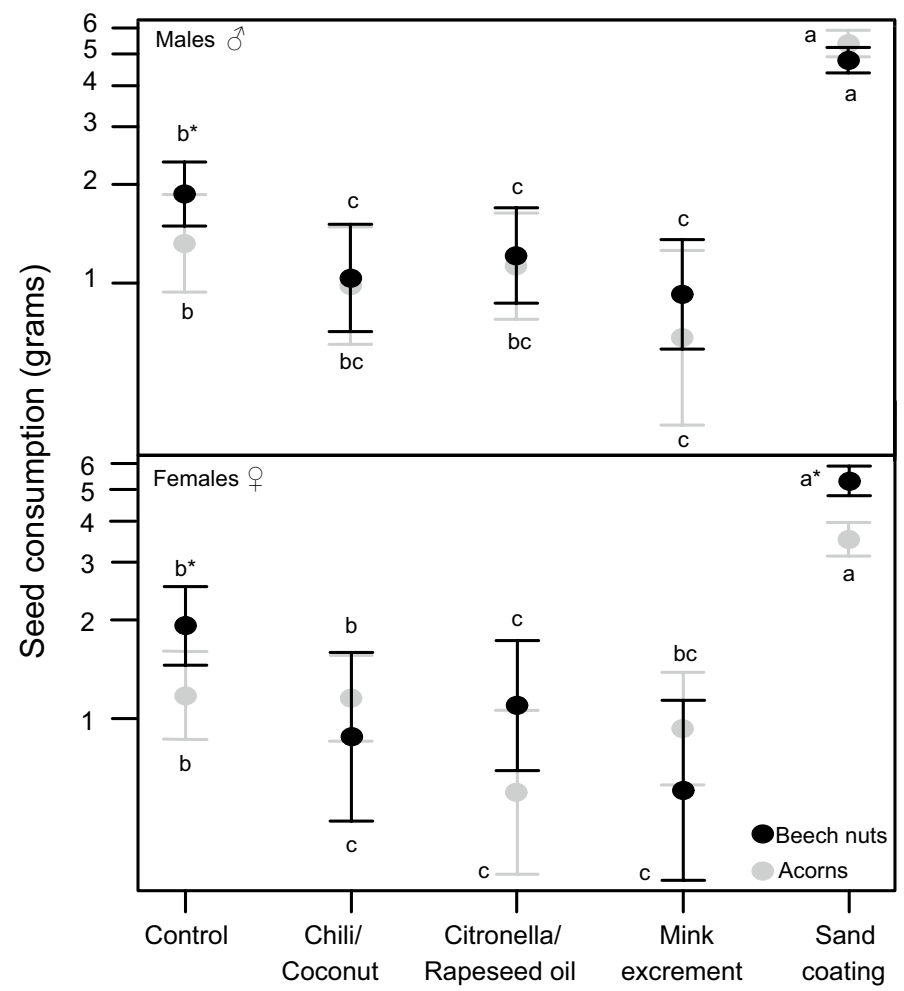

Fig. 1 Consumption of beech nuts and acorns by bank voles under different repellent treatments between males and females. Different letters indicate significant differences $(p<0.05)$ between treatments within sex and seed species combination. Black color represents beech nuts and gray color acorns. Asterisks indicate significant differences between beech nuts and acorns. Error bars represent the standard deviation of seed consumption of bank voles per treatment

$p=<0.01)$, and the control seeds in both males $(Z=-2.48, \mathrm{SE}=0.15, p=0.01)$ and females $(Z=-3.09, \mathrm{SE}=0.16, p=<0.01)$ were the only two treatments where significant differences between beech nuts and acorns were found (Online Resource 2). Significant differences were detected between males and females only in acorn consumption for citronella/rapeseed $(Z=-2.56, \mathrm{SE}=0.25, p=0.01)$ and sand coating $(Z=-3.96, \mathrm{SE}=0.11$, $p=<0.01)$.

The chili/coconut fat and mink excrement treatments significantly reduced the percentage of cages containing beech nuts that were touched compared with the other treatments (Fig. 2, Online Resource 3). In the other treatments almost all cages contained touched beech nuts. All beech nuts with sand coating were moved from their original position. For acorns, chili/coconut and mink excrement treated seeds reduced bank vole handling. The other three treatments showed the same proportion of cages with touched acorns (i.e. ca 75-100\%). Except for the mink excrement treatment, bank voles were more likely to touch beech nuts than acorns for all the other treatments (Fig. 2, Online Resource 4).

The germination capacity of beech nuts was significantly reduced by all repellent treatments, except for sand coating (Table 3, Online Resource 5). Most reduction occurred with the chili/coconut fat and citronella/rapeseed treatments. The same trends were found for 


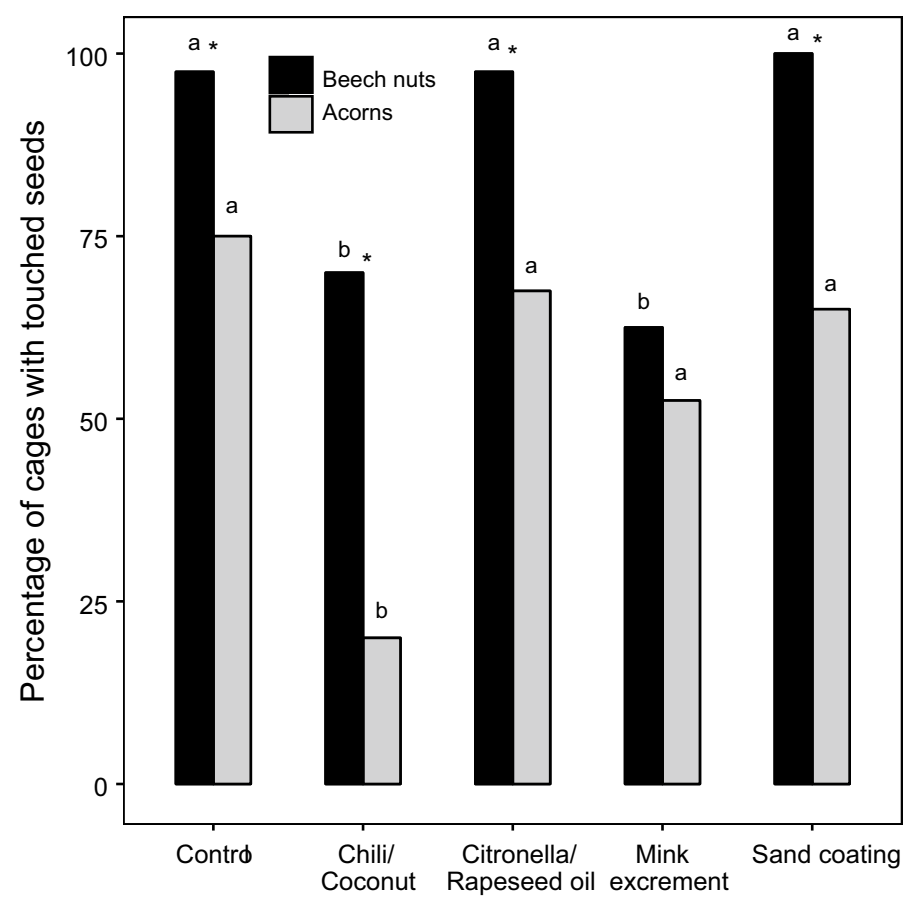

Fig. 2 Percentage of cages with seeds touched by bank voles in each repellent treatment and seed type. Black bars and gray bars represent cages with beech nuts and acorns, respectively. Different letters indicate significant differences $(p<0.05)$ between treatments over both sessions. Asterisks indicate differences between beech nuts and acorns

acorns. The reduction in germination capacity was, however, less pronounced compared to beech nuts after the chili/coconut fat and citronella/rapeseed treatments (Table 3). Both beech nuts and acorns retained a relatively high germination capacity after the mink excrement treatment. However, the percentage of germinated beech nuts after the mink excrement was significantly reduced when compared to the control treatment. The formation of beech germinants was unsuccessful since roots seemed to dry out after germination. Very few of the beech nuts that had not germinated after 14 weeks were viable. Contrarily, most germinated acorns that were still alive had developed a germinant.

\section{Discussion}

In our no-choice laboratory feeding study, the use of mink excrement was the most successful treatment as a repellent to deter bank voles from handling and eating beech nuts and acorns. The effects of various predator odors on many species of rodents have previously been described. (Apfelbach et al. 2005, 2015 and references therein). For example, sulfurous metabolites derived from meat ingestion were described to have a greater repellent effect in several prey species (Nolte et al. 1994; Apfelbach et al. 2005). Additionally, different prey behavioral responses have been observed when odors are from a predator with a vegetarian based diet (Apfelbach et al. 2015) or from "alien predators" 
Table 3 Results of the germination tests after 14 weeks. Sample size was 200 seeds per tree species/treatment combination. The ' $P$ ' column indicates significant differences within species at $p<0.05$ within tree species. After 14 weeks no germinants (with the first pair of leaves) of beech nuts were observed since roots tended to dry out in the vermiculite (acorns were kept in sand)

\begin{tabular}{|c|c|c|c|c|c|c|}
\hline Seed & Treatment & Germinated (\%) & $P$ & Germinants (\%) & $P$ & $\begin{array}{l}\text { Viable at cut- } \\
\text { test }^{\mathrm{a}}(\%)\end{array}$ \\
\hline \multirow[t]{5}{*}{ Beech nuts } & Control & 79.0 & $\mathrm{a}$ & - & & 2 \\
\hline & Chilli/coconut fat & 18.0 & $\mathrm{c}$ & - & & 2 \\
\hline & Citronella/rapeseed oils & 5.5 & d & - & & 4 \\
\hline & Mink excrement & 61.0 & $\mathrm{~b}$ & - & & 1 \\
\hline & Sand coating & 70.5 & $a b$ & - & & 1 \\
\hline Seed & Treatment & Germinated (\%) & $P$ & Germinants (\%) & $P$ & Live $\operatorname{root}^{\mathrm{b}}(\%)$ \\
\hline \multirow[t]{5}{*}{ Acorns } & Control & 73.5 & a & 61.5 & a & 3 \\
\hline & Chilli/Coconut fat & 51.5 & $\mathrm{~b}$ & 36.0 & $\mathrm{bc}$ & 6 \\
\hline & Citronella/Rapeseed oils & 51.5 & $\mathrm{~b}$ & 27.5 & $\mathrm{~b}$ & 8 \\
\hline & Mink excrement & 70.5 & $\mathrm{a}$ & 55.0 & ac & 3 \\
\hline & Sand coating & 62.5 & $a b$ & 49.0 & $\mathrm{abc}$ & 3 \\
\hline
\end{tabular}

${ }^{\text {a } V i a b l e ~ b u t ~ s t i l l ~ u n g e r m i n a t e d ~ a f t e r ~} 14$ weeks

${ }^{\mathrm{b}}$ Germinated and with living root but no germinant formed after 14 weeks

(Carthey et al. 2017). Moreover a field study from Sunyer et al. (2013) shows a significant reduction of acorn removal and predation when excrement scent of the common genet (Gnetta gnetta L.) was sprayed directly on acorns. However, the effect of mink excrement on consumption when applied to seeds has - to the best of our knowledgenot formerly been documented; neither has the influence of any predator excrements on germination capacity been reported in the literature. In this study, mink excrement slightly reduced germination capacity of beech nuts but had no significant impact on acorns.

The desired effect of a repellent for direct seeding is to completely prevent rodents from interfering with the seeds without reducing germination capacity. If it only stops the rodents from consuming seeds, not from removing and caching, the usefulness of the repellent could be completely lost, depending on where and how the seeds are cached. Similarly, the usefulness of a repellent is lost if it deters rodents but reduces seed germination. Therefore, the combined results of mink excrement for reduction of seed handling and seed consumption without reducing germination capacity highlights further recommendation for its applicability.

In general, rodents do not transport seeds long distances from where they find them (Wang and Chen 2008). Short dispersal distances indicate that the seeds may not leave the regeneration area during direct seeding, and that caching therefore is not a problem. However, the distribution of the emerging seedlings could be patchy especially if rodents cache seeds under logs, rocks and bushes, which are not suitable habitat for newly germinated seedlings due to increased seed consumption (Takahashi et al. 2006). In addition, even if germination is not reduced by caching, few of the cached seeds may survive long enough to produce seedlings if the rodents consume them after dispersal. Therefore, successful repellents need to have a proper durability of their active compounds for at least 3 to up to 4 months in order to protect the seeds until the first shoots emerge (Birkedal et al. 2010). 
The other treatments (chili/coconut fat, citronella/rapeseed and sand coating) in this study showed disadvantages as potential repellents. Treatments with chili/coconut fat and citronella/rapeseed showed a clear trade-off between reducing bank vole consumption of beech nuts and also the germination capacity. The citronella treatment did not decrease the handling of seeds as showed by the chili/coconut treatment. Hence, as they were applied in this study, these two treatments cannot be recommended as repellents to deter rodents. The results were also unfavorable for sand coating since this treatment increased seed consumption. This could be because the sand did not create the desired barrier, the application of the coating was unsatisfactory, or because the paste holding the sand contained palatable and nutritious ingredients, namely potato starch and sugar.

Contrasting results have previously been found when capsaicin has been tested together with various seeds as a repellent. Nolte and Barnett (2000), Jensen et al. (2003) and Willoughby et al. (2011) found positive effects against rodents, whereas Leverkus et al. (2013) found no effect on seed predation but a reduction of seed germination. However, the germination capacity of seeds treated with capsaicin has shown different results depending on the concentration used (Barnett 1998; Gosling and Baker 2004). In accordance with our results, others have also found a reduction in germination rate when seeds were mixed with citronella (Biswas and Biswas 2006).

For both the chili/coconut fat and the citronella/rapeseed oil treatments, further work is needed to determine if repellent effects were due to the repellent or the fatty carrier. In addition, the low germination rates in these two treatments may have resulted from the coconut fat and rapeseed oil which may have prevented re-hydration of the seeds or creation of anaerobic conditions (Lamond and Levert 1980). To be able to separate the effects of the fatty carriers from the effects of the intended repellent substances further germination tests, where seeds are treated with coconut fat or rapeseed oil only, are required. Furthermore, since seeds in these two treatments were not soaked in a water-based mixture, the poor germination rates might also be linked to a lower initial level of re-hydration than occurred in the other treatments.

In our no-choice laboratory feeding study, more beech nuts tended to be consumed, and they were moved around more than acorns. This is in accordance with previous laboratory research where bank voles prefer beech nuts to acorns (Jensen 1985), and with fieldbased direct-seeding experiments which indicate that beech nuts may be removed more rapidly than acorns (Birkedal et al. 2010). An average bank vole requires an energy intake of approximately $54 \mathrm{~kJ}$ per day during the summer (Grodzinski 1985), which corresponds to about 19 beech nuts or 2 acorns (Jensen 1985). This may explain, at least partly, why a much greater proportion of the beech nuts was consumed, since the bank voles in this study had access to more biomass of acorns, but less biomass of beech nuts than they needed to eat in 1 day.

A decrease in consumption, from males to females, was only found for acorns when treated with citronella/rapeseed oil and sand coating. This sex difference in acorn consumption may partly be in accordance with Hansen et al. (2016); and Shumake and Hakim (2000). Both suggested different responses of rodent females and males to secondary plant metabolites. Unfortunately, most of the scientific efforts are focusing on female responses rather than sex-specific responses to plant-based or predator-based repellents (Apfelbach et al. 2005; Hansen et al. 2016).

Voles' previous diet influences their food choices (Hansson 1993), and using wildcaught animals with an unknown dietary history might bias results. Laboratory-bred animals, with identical previous experiences, are therefore preferred in these types of test. Bank voles are furthermore easily maintained and handled in captivity, and since 
laboratory-bred animals are accustomed to the study environment, they are less stressed by the experimental conditions than wild-caught animals. This, however, does not mean that our no-choice feeding study is without objections from a methodological point of view. For example, any habituation effects were tested in the study by exposing the voles twice to each of the treatments. For a better understanding of habituation by rodents, longer-term trials may be useful. However, longer no-choice trials may not be appropriate for animal welfare reasons. Therefore, a multiple choice setup trial would be more desirable where the rodents have access to different food and smell sources, and natural conditions may also be better simulated using such cafeteria trials since wild-living rodents normally have access to many different food sources. On the other hand, a no-choice trial gives a strong indication of the potential of a substance since the rodent only has two options-handle the substance or not eating. Hence, we recommend the use of both multiple choice and no-choice set-ups in further studies.

In order to verify the consistency of our results, more tests including other rodent species are needed. In addition, experiments on consumption and germination capacity of beech nuts and acorns should also be tested in the field since the repellent effect can be affected by climatic conditions or other factors in situ (Gosling and Baker 2004; Willoughby et al. 2011).

\section{Conclusions}

In this no-choice feeding study, mink excrement showed potential as a repellent against bank voles. This treatment of seeds led to about a halving of losses of beech nuts, which were more preferred than acorns, compared to the control. To further reduce rodent impact during direct seeding this potential repellent could be used in combination with other measures to avoid rodent consumption such as covering the seed with soil, sowing in May rather than July, use mounding as site preparation technique, and/or sowing in large open regeneration areas with little cover for rodents (Birkedal et al. 2010). However, further studies to determine the best way of application, as well as the efficiency under field conditions, are needed before definitive recommendations can be given to restoration managers. Additionally, we strongly recommend further research on the application of excrements from more prey specific predators such as the least weasel (Mustela nivalis L.) or the stoat (Mustela erminea L.). The other seed treatments in this study, chili/coconut fat, citronella/rapeseed oil and sand coating, either reduced the germination capacity or increased the consumption of seeds by bank voles. However, the formula of these substances complicates the interpretation of the rodent consumption and germination results. Therefore, controls for the carriers or alternative ways of application are recommended for further studies on these potential repellents.

Acknowledgements We would like to thank Zarah Evling and Pia Ekeland for assistance during the laboratory work; Kristina Dahlborn and Jan-Eric Englund for suggestions concerning the experimental design and statistics; Leif Åbjörnsson and Nils-Arne Persson for providing material; Eugene Ezebilo and Emma Sandell for useful comments on the manuscript; Carl Salk for language improvement and Annika Schlötelburg and Adam Flöhr for help with the GLMM modelling. We are also grateful for the finance provided by the research program Sustainable Management in Hardwood Forests and from The Swedish Research Council for Environment, Agricultural Sciences and Spatial Planning (Formas).

Author contributions GO and MB planned and designed the study. MB performed all behavioral assays, the germination tests and contributed to writing the first draft. AV re-analyzed all the data and wrote the final draft of the manuscript together with ML. All authors revised the final version of the manuscript. 
Open Access This article is distributed under the terms of the Creative Commons Attribution 4.0 International License (http://creativecommons.org/licenses/by/4.0/), which permits unrestricted use, distribution, and reproduction in any medium, provided you give appropriate credit to the original author(s) and the source, provide a link to the Creative Commons license, and indicate if changes were made.

\section{References}

Apfelbach R, Blanchard CD, Blanchard RJ, Hayes RA, McGregor IS (2005) The effects of predator odors in mammalian prey species: a review of field and laboratory studies. Neurosci Biobehav Rev 29:1123-1144

Apfelbach R, Soini HA, Vasilieva NY, Novotny MV (2015) Behavioral responses of predator-naïve dwarf hamsters (Phodopus campbelli) to odor cues of the European ferret fed with different prey species. Physiol Behav 146:57-66

Barnett JP (1998) Oleoresin Capsicum has potential as a rodent repellent in direct seeding longleaf pine. In: Waldrop TA (ed) Proceedings of the ninth biennial southern silvicultural research conference, Asheville, NC, U.S, Department of Agriculture, Forest Service, Southern Research Station, pp 326-328

Bates D, Mächler M, Bolker B, Walker S (2015) Fitting linear mixed-effects models using lme4. J Stat Softw. https://doi.org/10.18637/jss.v067.i01

Bäumler W, Mielke H, Zahner V (1990) Behandlung von Eicheln mit Repellentien gegen Nagetierschäden. Anzeiger für Schädlingskunde 63:15-19

Bergquist J, Örlander G (1996) Browsing deterrent and phytotoxic effects of roe deer repellents on Pinus sylvestris and Picea abies seedlings. Scand J For Res 11:145-152

Birkedal M, Fischer A, Karlsson M, Löf M, Madsen P (2009) Rodent impact on establishment of directseeded Fagus sylvatica, Quercus robur and Quercus petraea on forest land. Scand J For Res 24:298-307

Birkedal M, Löf M, Olsson GE, Bergsten U (2010) Effects of granivorous rodents on direct seeding of oak and beech in relation to site preparation and sowing date. For Ecol Manage 259:2382-2389

Biswas N, Biswas A (2006) Use of non-edible oils as grain protectant against rice weevil (Sitophilus oryzae L.) and their subsequent effect on germination. Adv Plant Sci 19:653-656

Bolker BM (2018) GLMM FAQ. GitHub Inc. http://bbolker.github.io/mixedmodels-misc/glmmFAQ.html. Accessed 05 May 2018

Bolker BM, Brooks ME, Clark CJ, Geange SW, Poulsen JR, Stevens MHH, White J-SS (2009) Generalized linear mixed models: a practical guide for ecology and evolution. Trends Ecol Evol 24:127-135

Bolte A et al (2009) Adaptive forest management in central Europe: climate change impacts, strategies and integrative concept. Scand J For Res 24:473-482

Borowski Z (1998) Influence of predator odour on the feeding behaviour of the root vole (Microtus oeconomus Pallas, 1776). Can J Zool 76:1791-1794

Carthey AJ, Bucknall MP, Wierucka K, Banks PB (2017) Novel predators emit novel cues: a mechanism for prey naivety towards alien predators. Sci Rep 7:16377

Castro J, Leverkus AB, Fuster F (2015) A new device to foster oak forest restoration via seed sowing. New Forest 46:919-929

Ceccon E, González EJ, Martorell C (2016) Is direct seeding a biologically viable strategy for restoring forest ecosystems? Evidences from a meta-analysis. Land Degrad Dev 27:511-520

Chazdon RL (2008) Beyond deforestation: restoring forests and ecosystem services on degraded lands. Science 320:1458-1460

Demétrio CG, Hinde J, Moral RA (2014) Models for overdispersed data in entomology. In: Ferreira CP, Godoy WAC (eds) Ecological modelling applied to entomology. Springer, Cham, pp 219-259

González-Rodríguez V, Villar R (2012) Post-dispersal seed removal in four Mediterranean oaks: species and microhabitat selection differ depending on large herbivore activity. Ecol Res 27:587-594

Gosling PG, Baker C (2004) Six chemicals with animal repellent or insecticide properties are screened for phytotoxic effects on the germination and viability of ash, birch, Corsican pine and sycamore seeds. Forestry 77:397-403

Grodzinski W (1985) Ecological energetics of bank voles and wood mice. In: Symposia of the Zoological Society of London, pp 169-192

Hansen SC, Stolter C, Jacob J (2015) The smell to repel: the effect of odors on the feeding behavior of female rodents. Crop Prot 78:270-276 
Hansen SC, Stolter C, Imholt C, Jacob J (2016) Plant secondary metabolites as rodent repellents: a systematic review. J Chem Ecol 42:970-983

Hansson L (1993) Food preferences of voles related to post-weaning nutrition. Oikos 68:132-138

Hansson L (1971) Small rodent food, feeding and population dynamics: a comparison between granivorous and herbivorous species in Scandinavia. Oikos 22:183-198

Jędrzejewski W, Rychlik L, Jędrzejewska B (1993) Responses of bank voles to odours of seven species of predators: experimental data and their relevance to natural predator-vole relationships. Oikos 68:251-257

Jensen TS (1985) Seed-seed predator interactions of European beech, Fagus silvatica and forest rodents, Clethrionomys glareolus and Apodemus flavicollis. Oikos 44:149-156

Jensen PG, Curtis PD, Dunn JA, Austic RE, Richmond ME (2003) Field evaluation of capsaicin as a rodent aversion agent for poultry feed. Pest Manag Sci 59:1007-1015

Koca D, Smith B, Sykes MT (2006) Modelling regional climate change effects on potential natural ecosystems in Sweden. Clim Change 78:381-406

Lamond M, Levert J (1980) Influence des enveloppes séminales sur l'imbibition des glands de chêne pédonculé (Q. robur L.). Ann For Sci 37:73-83

Lenth RV (2018) Emmeans: estimated marginal means, aka least-squares means. R package version 1.1.2. https://CRAN.R-project.org/package=emmeans. Accessed 5 May 2018

Leverkus A, Castro J, Puerta-Piñero C, Benayas JR (2013) Suitability of the management of habitat complexity, acorn burial depth, and a chemical repellent for post-fire reforestation of oaks. Ecol Eng 53:15-22

Leverkus AB, Carrión M, Molina-Morales M, Castro J (2017) Effectiveness of diesel as a mammal repellent for direct seeding of acorns. Forests 8:276

Lindbladh M, Axelsson A-L, Hultberg T, Brunet J, Felton A (2014) From broadleaves to spruce-the borealization of southern Sweden. Scand J For Res 29:686-696

Löf M, Birkedal M (2009) Direct seeding of Quercus robur L. for reforestation: the influence of mechanical site preparation and sowing date on early growth of seedlings. For Ecol Manage 258:704-711

Löf M, Brunet J, Hickler T, Birkedal M, Jensen A (2012) Restoring broadleaved forests in southern Sweden as climate changes. In: Stanturf J, Madsen P, Lamb D (eds) A goal-oriented approach to forest landscape restoration. Springer, Dordrecht, pp 373-391

Madsen P, Löf M (2005) Reforestation in southern Scandinavia using direct seeding of oak (Quercus robur L.). Forestry 78:55-64

Myllymäki A (1975) Conventional control of field rodents and other harmful small mammals. Ecol Bull 19:113-127

Nilsson U, Gemmel P, Löf M, Welander T (1996) Germination and early growth of sown Quercus robur L. in relation to soil preparation, sowing depths and prevention against predation. New Forest 12:69-86

Nolte DL, Barnett JP (2000) A repellent to reduce mouse damage to longleaf pine seed. Int Biodeterior Biodegradation 45:169-174

Nolte DL, Mason JR, Epple G, Aronov E, Campbell DL (1994) Why are predator urines aversive to prey? J Chem Ecol 20:1505-1516

Nordlander G, Nordenhem H, Hellqvist C (2009) A flexible sand coating (Conniflex) for the protection of conifer seedlings against damage by the pine weevil Hylobius abietis. Agric For Entomol 11:91-100

Olsson GE, White N, Hjältén J, Ahlm C (2005) Habitat factors associated with bank voles (Clethrionomys glareolus) and concomitant hantavirus in northern Sweden. Vector-Borne Zoonotic Dis 5:315-323

R Core Team (2015) R: A language and environment for statistical computing 1.1.383 edn. R Foundation for Statistical Computing, Vienna, Austria

Rao NK, Hanson J, Dulloo ME, Ghosh K, Nowell A (2006) Manual of seed handling in genebanks, vol 8. Bioversity International, Rome, Italy

Reque JA, Martin E (2015) Designing acorn protection for direct seeding of quercus species in high predation areas. For Syst 24:018

Shumake SA, Hakim A (2000) Evaluating Norway rat response to attractant and repellant odors to improve rodenticide baiting effectiveness. In: Brittingham MC, Kays J, McPeake R (eds) The 9th wildlife damage management conference proceedings. State College, pp 103-110

Smit C, Díaz M, Jansen P (2009) Establishment limitation of holm oak (Quercus ilex subsp. ballota (Desf.) Samp.) in a Mediterranean savanna-forest ecosystem. Ann For Sci 66:1-7

Stoddart DM (1976) Effect of the odour of weasels (Mustela nivalis L.) on trapped samples of their prey. Oecologia 22:439-441

Sullivan TP (1979) The use of alternative foods to reduce conifer seed predation by the deer mouse, (Peromyscus maniculatus). J Appl Ecol 16:475-495 
Sullivan T, Crump D, Sullivan D (1988) Use of predator odors as repellents to reduce feeding damage by herbivores: III. Montane and meadow voles (Microtus montanus and Microtus pennsylvanicus). J Chem Ecol 14:363-377

Sunyer P, Munoz A, Bonal R, Espelta JM (2013) The ecology of seed dispersal by small rodents: a role for predator and conspecific scents. Funct Ecol 27:1313-1321

Szolcsanyi J (1990) Capsaicin, irritation, and desensitization: neurophysiological basis and future perspectives. Chem Senses 2:141-168

Takahashi K, Sato K, Washitani I (2006) The role of the wood mouse in Quercus serrata acorn dispersal in abandoned cut-over land. For Ecol Manage 229:120-127

Vander Wall SB (1998) Foraging success of granivorous rodents: effects of variation in seed and soil water on olfaction. Ecology 79:233-241

Wang B, Chen J (2008) Tannin concentration enhances seed caching by scatter-hoarding rodents: an experiment using artificial 'seeds'. Acta Oecol 34:379-385

Willoughby IH, Jinks RL, Morgan GW, Pepper H, Budd J, Mayle B (2011) The use of repellents to reduce predation of tree seed by wood mice (Apodemus sylvaticus L.) and grey squirrels (Sciurus carolinensis Gmelin). Eur J Forest Res 130:601-611

Ylönen H, Pech R, Davis S (2003) Heterogeneous landscapes and the role of refuge on the population dynamics of a specialist predator and its prey. Evol Ecol 17:349-369 